\section{Corporate governance mechanisms and intellectual capital}

\author{
Francisca Tejedo-Romero \\ University of Castilla-La Mancha, Business Administration \\ Department, Albacete, Spain
}

Joaquim Filipe Ferraz Esteves Araujo

University of Minho, International Relations and Public Administration Department, Braga, Portugal

Magnus Luiz Emmendoerfer

Federal University of Viçosa, Administration \& Accounting

Department, Viçosa, Brazil
Received on

02/24/2016

Approved on

02/10/2017

Responsible editor:

Profa $^{a}$ Dr $^{\mathrm{a}}$ Leire San-Jose

Evaluation process:

Double Blind Review

\begin{abstract}
Purpose - The purpose of this paper is to identify the corporate governance characteristics of Spanish companies included in the Ibex35 stock price index that influence the voluntary information disclosure policy regarding their Intellectual Capital.
\end{abstract}

Design/methodology/approach - The methodology used was content analysis of 115 annual reports from 23 Ibex 35 companies over five years; this allowed for the development of an index to quantify Intellectual Capital information.

Findings - Based on Agency-Stakeholders Theory postulates, the main results reveal that companies that disclose most information about their Intellectual Capital are those in which managers have greater managerial ownership, fewer independent directors, separation of functions between the chairman and the chief executive, and larger Boards of Directors.

Originality/value - With this study, we contribute to agencystakeholder theory by analyzing a non-Anglo-Saxon market (characterized by strong executive power and low protection of minority shareholders and other stakeholders), stating that certain characteristics of Corporate Governance condition the disclosure of Intellectual Capital.

Keywords - Intellectual capital; information disclosure; corporate governance; ownership structure; board of directors

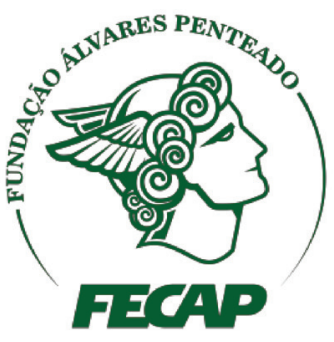

Review of Business Management

DOI: $10.7819 /$ rbgn.v19i65.3024 


\section{Introduction}

Knowledge can be identified as a business asset (Sveiby, 1997; Tejedo-Romero \& Araujo, 2016) that has become a key economic resource and the main competitive advantage (Brooking, 1997; Rodrigues, Tejedo-Romero \& Craig, 2017). Knowledge can have different origins such as people, the organization, technology and the market or socio-economic environment, forming what is called "Intellectual Capital" (IC) (European Commission, 2006). Many researchers argue that IC significantly increases a company's value (Bukh, Nielsen, Gormsen, \& Mouritsen, 2005; Rodrigues et al., 2017; Tejedo-Romero, \& Alfaro-Cortés, 2014; Yi \& Davey, 2010).

However, financial statements have ceased to be explanatory about the business reality on which they intend to report, since the identification, measurement and valuation criteria do not respond to the characteristics of knowledge economy (Beattie, 2005; TejedoRomero \& Araujo, 2016). Many stakeholders are at a disadvantage in terms of information access and are forced to heavily rely on voluntary IC disclosure for their decision-making (Rodrigues et al., 2017; Vergauwen, Bollen \& Oirbans, 2007). Thus, the purpose of IC disclosure should be to: a) provide relevant and quality information so that stakeholders can make efficient decisions (Abeysekera \& Guthrie, 2005; Tejedo-Romero, \& Alfaro-Cortés, 2014); b) reduce the asymmetries of information and improve relationships with stakeholders (Guthrie \& Petty, 2000; Rodrigues et al., 2017); c) improve transparency between companies' managers and owners and other stakeholders (Vergauwen, et al., 2007; Yi \& Davey, 2010); d) reduce the gap between the book value and the market value of the company (GarcíaMeca, Parra, Larrán \& Martínez, 2005); and e) create trust and reputation among stakeholders (Tejedo-Romero, 2016, Vergauwen, et al., 2007).

Companies are becoming aware of the importance of disclosing voluntary information (Bukh et al., 2005; Tejedo-Romero \& Araujo, 2016; Yi \& Davey, 2010), and it is Good
Corporate Governance (henceforth CG) that should provide the mechanisms necessary to increasing the degree and the quality of transparency. As García Osma and Gill de Albornoz (2007) point out, the influence that the company's management can exert on the quality of information is framed within the context of the agency problem that originates from the separation between ownership and company control (Jensen \& Meckling, 1976). This generates the presence of asymmetries between the principal (shareholders and other stakeholders) and the agent (managers/directors), in which the agent can use his power to achieve his own benefit against the interests of the principal (Jensen $\&$ Meckling, 1976). This has led to the use of good governance codes in most countries, establishing rules and recommendations that allow companies to adopt norms on the supervision of managers, aimed at reducing information asymmetries between shareholders and other stakeholders.

Few studies have attempted to establish relationships between IC disclosure, ownership structure and CG (Abeysekera, 2010; Cerbioni \& Parbonetti, 2007; Hidalgo, García-Meca, \& Martínez, 2011; Li, Pike, \& Haniffa, 2008; Rodrigues et al., 2017). Institutional and legal differences in individual countries, in particular their ownership structure and CG system (unitary or dual), can lead to significant variations in governance models and revealed information. On the other hand, we should note that studies carried out so far, such as the pioneering work by Cerbioni and Parbonetti (2007), point out a number of limitations that could be overcome by future research, such as extending the period of study, examining companies from different sectors and analyzing different institutional and legal contexts. This work tries to surmount these limitations, facing the scarcity of studies in Spain that examine the influence that ownership structure and GC characteristics of listed Spanish companies have on IC disclosure.

Spain offers an interesting framework for studying the effectiveness of the mechanisms 
of good governance in the disclosure of IC information, for several reasons: a) the legal protection of shareholders there is lower than in Anglo-Saxon markets (Gisbert \& Navallas, 2013), mainly of minority shareholders (PuchetaMartínez, 2015); b) Spanish capital markets are less developed than the United States', GreatBritain's and even Asian countries' markets (Fernández-Méndez \& Arrondo-García, 2007; Pucheta-Martínez, 2015); c) the requirement for all listed companies, through Law 26/2003 of July 17 , of having a website to provide relevant information and prepare a corporate governance report (Gisbert \& Navallas, 2013; Tejedo-Romero $\&$ Araujo, 2016); d) the relevant role that the Board of Directors (henceforth BD) acquires in unitary or monist government systems (onetier-system), as it is in charge of the control and supervision of the company's management team, promoting active participation in strategic decision-making (Acero Fraile, \& Alcalde Fradejas, 2010; García-Sánchez, Rodríguez Dominguez, \& Gallego Álvarez, 2011); and e) the existence of a highly concentrated ownership structure (García Osma \& Gill de Albornoz, 2007; Gisbert \& Navallas, 2013), in which institutional directors have a significant influence on Spanish BDs (Pucheta-Martínez \& García-Meca, 2014); because in Spain, in addition to executive or internal directors (insider), who hold a managerial position in the company and are directly involved in management, non-executive or outsider directors are considered as: Institutional Directors, which represent the interests of shareholder groups capable of influencing the control of the company (majority shareholders); independent directors, who are not connected either to the management team or to the control groups, but are selected for their high professional training and are responsible for ensuring the interests of minority shareholders; and other outsider directors (Law 31/2014, article 529).

This paper aims to identify the characteristics of Spanish Ibex35 companies' CG that affect the policy of IC disclosure. These companies are the ones that make up the bulk of capital movements in the Spanish stock market. In addition, they are a reference, since, for the development of the first CG code (Olivencia Report), they were the target of a survey to understand the structure of shareholders and Boards of Directors in listed Spanish companies. For the analysis of the data, a regression model is used for balanced panel data, using the HausmanTaylor estimator to solve the endogeneity problem of variables. The results suggest that the ownership structure and certain characteristics of the $\mathrm{BD}$, such as the number of directors, the role of independent directors and the separation of the roles of $\mathrm{BD}$ chairman and $\mathrm{CEO}$, play an important role in the decision to disclose IC.

From the perspective of agency-stakeholder theory, our research contributes in various ways to existing literature on the discussion of CG mechanisms that affect IC disclosure in agency relationships. First, it provides evidence to limited research in the Spanish context regarding the influence that CG has on IC disclosure. In particular, it enhances the knowledge of the determinants for IC disclosure in a nonAnglo-Saxon capital market, characterized by an ownership structure concentrated in large shareholders and by the strong power the executive directors have, due to the scarce separation of powers between the roles of the chairman of the $\mathrm{BD}$ and $\mathrm{CEO}$. In addition, it highlights the lack of effectiveness of independent BDs as a control mechanism contributing to safeguard the interests of minority shareholders and other stakeholders. Secondly, it is a longitudinal study that covers a period of five years, extending previous work which only analysis one or two years in Spain (García-Meca et al., 2005; Macagnan, 2009; Monclús Guitart, Rodríguez Merayo, \& Torres Coronas, 2006; Oliveras, Gowthorpe, Kasperskaya, \& Perramon, 2008), except for the research of Alcaniz, Gomez-Bezares and Ugarte (2015), which covers the period between 1996 and 2007. Thirdly, the use of panel data methodology, which has not been widely 
used in IC studies, improves the efficiency of econometric estimates by capturing unobservable heterogeneity (Baltagi, 2014; Wooldridge, 2010). Finally, the endogeneity problem of CG variables is also addressed; this has its origins in the causal relationship between these variables and corporate disclosure (Gul \& Leung, 2004) by using the Hausman-Taylor estimator.

\section{Theoretical framework and development of hypotheses}

\section{I Spanish regulation and context}

A Committee of Experts was created to analyze the accounting situation in Spain and how to approach the adaptation of the Spanish accounting system to international accounting standards. The result of the work was the wellknown "ElLibro Blanco de la Contabilidad"(ICAC, 2002). This document highlighted the relevance of IC and recommended the development of indicators that reflect the status of intangible elements that are part of the corporate patrimony, as well as disclosure and standardization among companies that voluntarily want to use them in their financial information, through IC reports or within sections of the Annual Report (Instituto de Contabilidad y Auditoría de Cuentas [ICAC], 2002), since the latter is the main corporate communication channel of the companies' activities and future intentions (Abeysekera \& Guthrie, 2005; Tejedo Romero \& Araujo, 2016).

In Spain, most of the research that studies IC voluntary information has analyzed annual reports (Macagnan, 2009; Monclús et al., 2006; Oliveras et al., 2008). Alcaniz et al. (2015) explored the Initial Public Offerings' (IPOs) prospectuses, and García-Meca et al. (2005) focused on examining reports issued by financial analysts, while, according to Tejedo-Romero and Araujo (2016), the levels of voluntary information collected in the annual reports directly refer to the amount of information that companies publish in the media, either in environmental reports, responsibility reports, company website, reports from financial analysts etc. For this reason, this work will analyze annual reports.

On the other hand, CG in Spain has been driven mainly by several CG codes: the Olivencia Report was launched in 1998, followed by the Aldama Report in 2003 and the Conthe Code or the Unified Code in 2006, which was modified in 2013 and 2015. These codes are characterized by the principle of compliance or explanation, that is, companies can comply or not with the recommendations of the code. However, they have to explain when they do not follow them.

\subsection{Voluntary disclosure of information on intellectual capital}

Many efforts have been made by academics and researchers, agencies, institutions and organizations that have tried to establish management models for the purpose of identifying, measuring and managing IC (European Commission, 2006; Sveiby, 1997) as well as the development of guidelines and guides to disseminate information about IC, such as the Danish (Danish Agency for Trade and Industry [DATI], 2000), Nordic (Nordic Industrial Fund [NORDIKA], 2001), German (Federal Ministry of Economics and Labour [FMEL], 2004), Japanese (Ministry of Economy, Trade and Industry [METI], 2005), European (Meritum Project, 2002) guides and the $3 \mathrm{R}$ model (Ordoñez de Pablos, 2004), among others.

Over the last decades, the number of studies referring to the disclosure of IC information has increased (García-Meca et al., 2005, Goebel, 2015, Rodrigues et al., 2017, Yi \& Davey, 2010). Many of them are based on the initial framework of Sveiby (1997), later modified by Guthrie and Petty (2000) and replicated by other authors (Abeysekera \& Guthrie, 2005; Bozzolan, Favotto, Ricceri, 2003; Oliveras et al., 2008; Tejedo-Romero \& Alfaro-Cortés, 2014 to classify IC information into categories composed of a series of specific intangible elements. They are chosen usually based on literature concerning IC (Brooking, 1997; Sveiby, 1997), on guidelines and 
recommendations by several institutions (DATI, 2000; Meritum Project, 2002; on the Danish Ministry of Science Technology and Innovation [DMSTI], 2003) and on empirical studies referring to IC disclosure (Abeysekera \& Guthrie, 2005; Bozzolan et al., 2003; García-Meca et al., 2005; Guthrie \& Petty, 2000).

Many previous studies have descriptively analyzed the amount of information supplied by companies in a given country, during a short period of time of one or two years (Abeysekera, 2010; Abeysekera \& Guthrie, 2005; An, Davey, Eggleton, \& Wang, 2015; Bozzolan et al., 2003; García-Meca et al., 2005; Goebel, 2015; Guthrie \& Petty, 2000; Hidalgo et al., 2011; Li et al., 2008; Macagnan, 2009; Monclús et al., 2006; Oliveras et al., 2008; Tejedo-Romero \& AlfaroCortés, 2014; Whiting \& Miller, 2008; Yi \& Davey, 2010).

There are few longitudinal studies, however; we highlight those carried out by Abhayawansa and Guthrie (2016), Alcaniz, et al. (2015), Bukh et al. (2005), Tejedo-Romero and Alfaro-Cortés (2014) etc. All of them conclude that there is an increasing tendency towards disseminating IC information. Nonetheless, the work of Rodrigues et al. (2017) shows that there was stagnation in the provision of IC information during the crisis period.

Many of the aforementioned studies have tried to analyze the factors that influence IC disclosure, mainly companies' characteristics such as size, sector, market to book, indebtedness and profitability, among others (Alcaniz et al., 2015; Bozzolan et al., 2003; García-Meca et al., 2005; Goebel, 2015; Tejedo-Romero \& Alfaro-Cortés, 2014; Whiting \& Miller, 2008); as well as the CG mechanisms that affect IC disclosure (Abeysekera, 2010; Cerbioni \& Parbonetti, 2007; Hidalgo et al., 2011; Li et al., 2008; Rodrigues et al., 2017).

Nevertheless, the reasons why companies disclose voluntary information about their IC are based on a series of theories (Tejedo-Romero \& Alfaro-Cortés, 2014). There is not a single theory, and different researchers use different theories to explain the additional supply of information. This research will be based on the stakeholder, stakeholder-agency and signaling theories.

Stakeholder theory is based on the relationships a company has with a variety of stakeholders. This theory refers to the term accountability when it refers to a company's responsibility to be accountable not only to its shareholders but also to other stakeholders, in order to help them make appropriate decisions (An et al., 2015; Guthrie, Petty, Yongvanich, \& Ricceri, 2004). The positive approach (management) of this theory tries to focus on the stakeholders who have more power and influence on the viability and success of the company. Therefore, IC disclosure can be used to manage stakeholders' interests in order to gain their support and approval (Guthrie et al., 2004; Yi \& Davey, 2010), by increasing the perceived value they have of the company (Abeysekera \& Guthrie, 2005; TejedoRomero \& Alfaro-Cortés, 2014).

Following Acero Fraile and Alcalde Fradejas (2010), our study is based on the stakeholder approach, because it is more appropriate in continental European countries in which a system based and focused on relationships predominates - unlike Anglo-Saxon countries, in which predominates a system based on the market and oriented to satisfy the needs and interests of the shareholders.

The stakeholder-agency theory perspective considers the company as a set of socio-economic agents (Hill \& Jones, 1992), brought together by contracts that define the rules of actions carried out within it (agency relationships between principal and agent) (An et al., 2015; Li et al., 2008; Rodrigues et al., 2017). Asymmetries of information between the parties (principalagent) generate a conflict of interest between owners and managers; majority and minority shareholders; and managers or owners and potential investors or other stakeholders. IC disclosure can be an important way to reduce information asymmetries so that shareholders, investors and other stakeholders can make 
efficient decisions by having information about main value creators in the long term (Cerbioni $\&$ Parbonetti, 2007; Guthrie \& Petty, 2000; TejedoRomero \& Alfaro-Cortés, 2014)

The signalling theory presents connections with the previous theories. The company sends signals to stakeholders about certain characteristics that are a source of competitive advantage in the market (Guthrie \& Petty, 2000; Tejedo-Romero \& Alfaro-Cortés, 2014) in order to reduce information asymmetries. IC disclosure can be an effective way for companies to signal their superior quality because of the relevance of IC to wealth generation (Vergauwen et al., 2007; Whiting \& Miller, 2008).

\subsection{Good corporate governance}

Good CG must provide the necessary mechanisms to increase the degree of transparency and the quality of the disclosed information (Rodríguez-Ariza, Frías-Aceituno, \& García Rubio, 2014). To this end, the ownership structure and the characteristics and structure of the BD are studied as mechanisms for the good functioning of CG that can influence IC disclosure.

\subsection{Ownership structure}

Ownership structure is defined as the degree of participation in the property of the company that determines the distribution of power and control (Briano Turrent \& Saavedra Garcia, 2015). Managers are the only interest group that has a contractual relationships with the rest of the stakeholders (García-Sánchez, Cuadrado-Ballesteros, \& Sepulveda, 2014), and a conflict of interests may arise between them. Thus, under the stakeholder-agency theory, a greater percentage of the shares held by managers (directors and senior officers) can serve as a mechanism to align interests with other owners and stakeholders (Eng \& Mak, 2003; Jensen \& Meckling, 1976). Therefore, managers, when participating in the capital of the company, will have less incentive to behave opportunistically and harm the rest of the shareholders, employees, creditors, customers, suppliers, investors etc. Specifically, in the Spanish case, Monterrey Mayoral and Sánchez-Segura (2008) found that the participation of the management team in the ownership of the company has a beneficial effect on the quality of the information disclosed. Thus, managers will be interested in sending signals to the market through IC disclosure, so that all stakeholders referring to the company and, in particular, potential investors are aware of the main resources that generate long-term value, in order to increase the liquidity and value of the company's shares (Hidalgo et al., 2011), and to promote the company due to the future benefits that can be obtained in public share offerings (Bukh et al., 2005). IC information can be considered a control mechanism oriented to align interests between managers and stakeholders. This leads us to raise our first hypothesis:

H1: Companies in which managers have greater shareholder control are the ones that provide more IC information

\subsubsection{Board of directors}

The $\mathrm{BD}$ is the main governing body of the company, and is entrusted with the competencies of supervision and control over the management team (Gul \& Leung, 2004), as well as with guidance, collaboration and advice (Acero Fraile \& Alcalde Fradejas, 2010; Pucheta-Martínez, 2015), to ensure the interests of all stakeholders. From the perspective of the stakeholder-agency theory, the BD should focus on achieving the well-being of all stakeholders, safeguarding their interests and accountable to them (Rodríguez-Ariza et al., 2014) especially being in charge of managing and determining the disclosure of voluntary information in annual reports that protect the interests of all stakeholders (García-Sánchez et al., 2014; Li et al., 2008). There are various devices within the $\mathrm{BD}$, such as independence, separation of functions and size, that can improve supervision, control, guidance 
and counseling, thus reducing information asymmetries and lessening conflicts of interest between the parties.

\section{Board independence:}

Board independence is a mechanism for supervision and control of the actions carried out by the managers of the company (Jensen $\&$ Meckling, 1976; Lim, Matolcsy \& Chow, 2007). Independence is often associated with the presence of non-executive directors (García-Sánchez et al.; 2011; García-Sánchez, et al., 2014; Gisbert \& Navallas, 2013; Prado Lorenzo, García-Sanchéz \& Gallego-Álvarez, 2009; Pucheta-Martínez, 2015). These directors are more interested in creating greater long-term value (Pucheta-Martínez, 2015), presenting more responsible behavior that protects the interests of stakeholders (Acero Fraile \& Alcalde Fradejas, 2010; García et al., 2011); they are more objective and independent in the analysis of the management and behavior of the company (Prado Lorenzo et al., 2009; RodríguezAriza et al., 2014) and in being accountable to stakeholders. These attitudes foster the quality and quantity of the disclosed corporate information (Gisbert \& Navallas, 2013; Lim et al., 2007). Although the degree of board independence is a highly desirable feature, empirical evidence has found mixed results between independence and information disclosure. Some authors, such as Al-Moataz and Hussainey (2012), Barako, Hancock and Izan (2006), Eng and Mak (2003), Gul and Leung, (2004), Rodrigues et al., (2017), have found a negative impact. Others have found a positive relationship (Barako \& Brown, 2008; Briano Turrent \& Saavedra Garcia, 2015; Cerbioni \& Parbonetti, 2007; Li et al., 2008; Lim et al., 2007); and Ghazali and Weetman, (2006); Haniffa and Cooke, (2002) and Hidalgo et al., (2011) have not detected any influence. This divergence may be justified by: $a$ ) greater presence of independents may lead minority shareholders and stakeholders to demand less information, as a consequence of the greater trust placed in them as they defend their interests (Rodrigues et al., 2017); b) an excessive number of independents can affect the efficiency of the BD, since they do not carry out executive tasks (Monterrey Mayoral \& Sánchez-Segura, 2008); c) independent directors are not necessarily independent (Li et al., 2008); and $d$ ) the power of executives directors who can make decisions without taking independent directors into consideration (García-Sánchez et al., 2011). These reasons were chosen because the Spanish market is characterized by companies with a $\mathrm{BD}$ in which executive directors have greater power; this would cause a substitution effect by downplaying the role that independents should perform within the BD. Accordingly, the following hypothesis is presented:

H2: Companies whose BD directors are more independent are the ones that provide less IC information.

\section{Separation of CEO and chairman roles:}

The separation of the functions of chief executive officer (CEO) and chairman of the BD is also usually associated with an independent $\mathrm{BD}$ (Prado Lorenzo et al., 2009). The concentration of much power in the hands of a single person (duality) can lead to ineffective and opportunistic behaviors (Jensen \& Meckling, 1976), developing strategies that favor his personal interests to the detriment of the company's ones (García-Sanchéz, et al., 2011; Prado Lorenzo et al., 2009). This can lead to a loss of transparency of the company (Briano Turrent \& Saavedra Garcia, 2015; Gul \& Leung, 2004) as well as the elaboration and publication of low-quality information (PuchetaMartínez, 2015).

Most studies argue that duality limits BDs' independence and reduces BDs' ability to perform its functions of control, supervision, and counseling (Briano Turrent \& Saavedra Garcia, 2015; Prado Lorenzo et al., 2009) affecting the 
information disclosure policy of the company (Allegrini \& Greco, 2013, Li et al., 2008, PuchetaMartínez, 2015). However, the works of Cerbioni and Parbonetti (2007), Gul and Leung (2004) and Rodrigues et al. (2017) concluded that duality has a negative association with information disclosure. The studies conducted by Hidalgo et al. (2011) and Li et al. (2008), although, found no significant relationship with IC disclosure.

In Spain, it is recommended that companies adopt measures to avoid excessive concentration of power in the hands of the same person (Comisión Nacional del Mercado de Valores [CNMV], 2006). Therefore, the separation of roles will help to improve the supervisory function (Briano Turrent \& Saavedra Garcia, 2015), the quality of the disclosed information (Haniffa \& Cooke, 2002) and the transfer of relevant information among BD members (García-Sanchéz et al., 2011; Gisbert \& Navallas, 2013), in particular the one referring to IC. Thus, we propose the following hypothesis:

H3: Companies whose CEO and chairman have separate functions are the ones that provide more IC information.

\section{Board size:}

Gisbert and Navallas (2013) argue that large companies are under pressure of a larger number of stakeholders who demand more information and that the size of the company is related with the board size. Size has a significant influence on BD efficiency, effectiveness and supervision (Hidalgo et al., 2011, Rodrigues et al., 2017). Large BDs are more likely to provide more information (Gisbert \& Navallas, 2013).

Empirical evidence has obtained mixed results. Cerbioni and Parbonetti (2007) and Lim et al. (2007) found a negative association between the board size and the level of voluntary information. On the other hand, the works of Abeysekera (2010), Allegrini and Greco (2013),
Briano Turrent and Saavedra Garcia (2015), Gisbert and Navallas, (2013), Hidalgo et al. (2011) found a positive association between board size and the level of revealed information.

In Spain, boards are advised to not harbor less than five or more than 15 members (CNMV, 2006). A large number of members in the BD may lead to: $a$ ) a lower likelihood that it will be controlled by management (Al-Moataz \& Hussainey, 2012), b) an increase in diversity and experience BD (Gisbert \& Navallas, 2013; Hidalgo et al., 2011; Rodríguez-Ariza et al., 2014) and c) an improvement in the decisionmaking process and in the level of the provided information (Briano Turrent \& Saavedra Garcia; Gisbert \& Navallas, 2013). We argue that large $\mathrm{BDs}$ are beneficial because they bring together a greater set of expertise and experience of all its members at the disposal of the company. The following hypothesis is proposed:

H4: Companies whose board sizes are greater are the ones that provide more IC information.

\section{Research methodology}

\section{I Sample and data collection}

This study focuses on listed Spanish companies included in the Ibex35 stock index, as they are more susceptible to greater information transparency (Briano \& Rodríguez, 2013; De los Rios, Torres, Tirado, \& Carbonell, 2009; Tejedo-Romero \& Araujo, 201 Briano Turrent \& Rodríguez-Ariza, 2013; Ríos Berjillos, Torres Jiménez, Tirado Valencia, \& Carbonell Peralbo, 2009; Tejedo-Romero \& Araujo, 2016). These companies are obliged to comply with the requirements established in Law No. 26/2003 of July 17, regarding information transparency, specifically having a web page to provide information to interested parties, reason why the access to the annual and CG reports is more accessible. 
The sample units correspond to the annual reports. The final sample consists of 115 annual reports corresponding to the 23 companies that have remained for five years in the index (2004-2008). It was chosen a non-probabilistic sample design (Hernández Sampieri, Fernández Collado, \& Baptista Lucio, 2006) that considers the companies included in the Ibex35 in 2004 and maintain the same companies for years until 2008 (Ríos Berjillos et al., 2009). Therefore, the same companies are studied over the five years (balanced data). The Ibex35 companies are selected at 31 December of 2008 for two reasons. One is conjunctural, since the global economic crisis began in 2008, there is an atypical scenario with more instability, variations and contingencies that can generate wrong analysis because there is no proven evidence of overcoming it by international organizations. In this line, Abhayawansa and Guthrie (2016), who analyze IC disclosure in financial analysts' reports in
Australia during 2003-2008, justify their period of analysis by stating that their choice is motivated by the impact of the global financial crisis, as the disclosure of information would be affected by external economic and political concerns rather than by factors internal to the company. This is a more reliable way for measuring IC disclosure. This reason was also supported by Alcaniz et al., (2015) who studied IC disclosure in the Spanish Initial Public Offerings (IPOs) prospectuses from 1996 to 2007. On the other hand, after 2008, there were major alterations in the composition of the Ibex35 due to the mergers of large business groups and outflows of companies motivated by the crisis (Tejedo-Romero, 2016). The other motivation is methodological, prioritizing an ex-ante crisis period may be useful in future researches for ex-post crisis analysis.

The representativeness of the final sample of the starting population is $65.7 \%$ and all industrial sectors are characterized (see Table 1).

Table 1

Companies by sectors in the sample and in the population

\begin{tabular}{|c|c|c|c|c|}
\hline \multirow{2}{*}{ Sectors } & \multicolumn{2}{|c|}{ Initial population } & \multicolumn{2}{|c|}{ Final sample } \\
\hline & Companies & Percentage & Companies & Percentage \\
\hline Consumer Goods & 2 & $5.71 \%$ & 1 & $4.35 \%$ \\
\hline Basic Materials / Industry and Construction & 11 & $31.43 \%$ & 6 & $26.09 \%$ \\
\hline Oil and Energy & 8 & $22.86 \%$ & 7 & $30.43 \%$ \\
\hline Consumer Services & 3 & $8.57 \%$ & 2 & $8.70 \%$ \\
\hline Financial and Real Estate Services & 9 & $25.71 \%$ & 5 & $21.74 \%$ \\
\hline Technology and Telecommunications & 2 & $5.71 \%$ & 2 & $8.70 \%$ \\
\hline Total & 35 & $100 \%$ & 23 & $100 \%$ \\
\hline
\end{tabular}




\subsection{Measurement of variables}

\section{Dependent variable}

In order to quantify the level of information on intellectual capital, an unweighted disclosure index has been developed (Cerbioni \& Parbonetti, 2007, Tejedo-Romero, 2016). Using the methodology of content analysis, qualitative and quantitative information has been codified into previously defined categories (Krippendorff, 1997). The selection of these categories and the items that comprise each category have been based on previous literature (Brooking, 1997; Sveiby, 1997, etc.), guidelines and recommendations of many institutions (Comisión Europea, 2006; DATI, 2000; Meritum Project, 2002; NORDIKA, 2001; Ordoñez de Pablos, 2004) and empirical studies on IC disclosure in different countries (An et al., 2015; Bozzolan et al., 2003; Goebel, 2015; Guthrie \& Petty, 2000; Yi \& Davey, 2010, etc.) and in Spain (Alcaniz et al., 2015; García-Meca et al., 2005; Macagnan, 2009; Oliveras et al., 2008; Tejedo-Romero \& AlfaroCortés, 2014).

First, a pilot test was conducted in four annual reports randomly chosen to obtain a final list of items that best describe the elements that are disclosed by Spanish companies. The items that have eventually been considered are shown in Table 2. Aiming to guarantee the reliability of the content analysis, it has been used two encoders that have been trained for a long period and that the coding decisions have reached an acceptable level in the pilot sample, obtaining a
Krippendorff's alpha of 0.82 (Guthrie et al., 2004; Rodrigues et al., 2017).

$$
I C I_{i}=\frac{1}{53} \sum_{i=1}^{53} x_{i j}
$$

The development of the IC index is as follows:

Where $I C I_{j}$ is the absolute unweighted IC disclosure index of a company $j ; i$ are the items; $j$ is the company and, $\mathrm{X}_{\mathrm{ij}}$ is the score obtained for item $\mathbf{i}$ in company $\mathbf{j}$. So, $\mathrm{X}_{\mathrm{ij}}$ will be 1 if the company $j$ has disclosed the item $i$ and it will be 0 otherwise.

This unweighted index considers that all information items have the same importance (Beretta \& Bozzolan 2008; Briano Turrent \& Saavedra Garcia, 2015) and is consistent with the approach adopted by Alcaníz et al. (2015), GarcíaMeca et al. (2005), Macagnan (2009), Rodrigues et al. (2017) and Tejedo-Romero and AlfaroCortés, (2014). In addition, an adjustment was made dividing them by the maximum number of items that could be disclosed, thus, not penalizing those companies that for some reason could not provide an item (Botosan, 1997; Marston \& Shrives, 1991). We do not use indices weighted by the degree of subjectivity that have the weights, because there is no universally accepted weighting table, but each item is assigned a different score depending on the importance established by the researcher (Tejedo-Romero \& Araujo, 2016). 
Table 2

Items considered in the elaboration of the IC disclosure index

\begin{tabular}{|c|c|c|}
\hline \multicolumn{3}{|c|}{ IC } \\
\hline 1. Employee Profile & 21. Patents & 33. Financial relationships \\
\hline 2. Equality and diversity & 22. Copyrights & 34. Brands \\
\hline 3. Safety and Health & 23. Trade secrets & 35. Name of relevant customers \\
\hline 4. Labor relationships and trade union activity & 24. Trademarks & 36. Customer Loyalty \\
\hline 5. Involvement of workers with the community & 25. Management Philosophy & 37. Customer Satisfaction \\
\hline 6. Employee Recognition & 26. Corporate Culture & 38. Customer services and support \\
\hline 7. Outstanding Employees & 27. Management Processes & 39. Name of the company \\
\hline 8. Employee Commitment & 28. Technological Processes & 40. Favorable contracts \\
\hline 9. Employee Motivation & 29. Research and Development & 41. Environmental protection measures. \\
\hline 10. Employee Behavior & 30. Innovation & 42. Sponsorship and patronage \\
\hline 11. Economic data & 31. Information systems & 43. Social responsibility / Social action \\
\hline 12. Formal education & 32. Networking systems & 44. Company governance \\
\hline 13. Professional qualification & & 45. Collaboration with companies \\
\hline 14. Employee training & & 46. Franchise Agreements \\
\hline 15. Employee development & & 47. License Agreements \\
\hline 16. Know-how & & 48. Relationships with suppliers \\
\hline 17. Professional experience & & 49. Relationships with the Public \\
\hline 18. Seniority of the experts & & Administration \\
\hline 19. Performance and results of senior managers & & 50. Relationships with research centers \\
\hline \multirow{3}{*}{ 20. Entrepreneurial spirit } & & 51. Relationships with the media \\
\hline & & 52. Relationships with other stakeholders \\
\hline & & 53. Distribution Channels \\
\hline
\end{tabular}

\section{Independent variables}

Data was obtained from the CG Report. The measurement is described below (Table 3):

Table 3

\section{Independent variables and measures}

\begin{tabular}{ll}
\hline Variable & Measure \\
\hline Shareholder control of managers & $\begin{array}{l}\text { Numerical variable that represents the percentage of shares in the hands of directors and } \\
\text { senior officers. }\end{array}$ \\
Board independence & $\begin{array}{l}\text { Numerical variable representing the percentage of independent directors in the BD. } \\
\text { Dummy variable that takes the value of } 1 \text { in case of separation of functions and 0 } \\
\text { otherwise. }\end{array}$ \\
& $\begin{array}{l}\text { Numerical variable that represents the total number of directors that compose BD. In } \\
\text { addition, it is included the square of this variable, called "Board Size" which will allow } \\
\text { for determining a possible U-shaped relation between the board size and IC disclosure. }\end{array}$ \\
Board size & $\begin{array}{l}\text { This idea was used, for example, by Rodrigues et al. (2017) to analyze the relationship } \\
\text { between board size and IC disclosure in Portuguese companies. }\end{array}$ \\
\hline
\end{tabular}

\section{Control variables}

The following control variables have been considered:

- $\quad$ Size of the company: numerous empirical researches confirm that size has a positive impact on the level of information disclosure (Bozzolan et al., 2003; Eng \& Mak, 2003; García-Meca et al., 2005;
Hidalgo et al., 2011; Rodrigues et al., 2017; Tejedo-Romero \& Alfaro-Cortés, 2014). It was measured by taking the logarithm of the total assets (Bozzolan et al., 2003; Goebel, 2015).

- Market to Book: this value is attributed to the value of companies' hidden intangibles (Brooking, 1997; Sveiby, 1997). It was measured as the quotient 
between the capitalization value and the book value of the net worth at the end of the accounting year (Tejedo-Romero \& Alfaro-Cortés, 2014; Vergauwen et al., 2007).

- Industry/sector: empirical evidence has corroborated that companies in the intangible-intensive sectors disclose more information than those with less intangible resources (Hidalgo et al., 2011; Li et al., 2008; Tejedo-Romero \& AlfaroCortés, 2014; Vergauwen et al., 2007).

- Dummies were considered for each of the sectors, taking on value 1 if the company belongs to the sector in question, and value 0 if it does not belong to it (Hidalgo et al., 2011).

The information of these variables was compiled from the Annual Reports and, when it has not been possible to obtain them, from the SABI/AMADEUS database.

\subsection{Research model}

We used an econometric model of panel data that has cross-sectional (23 companies) and temporal (five years) data, allowing a greater number of observations $(115=\mathrm{NxT})$ and degrees of freedom (Ríos Berjillos et al., 2009). This technique improves the efficiency of econometric estimations by capturing unobservable heterogeneity: a) specific individual effects of each company and, b) temporal effects (Baltagi, 2014; Ríos Berjillos et al., 2009; Hsiao, 2003; Wooldridge, 2010).

The aim of this work is to identify Ibex 35 companies' CG characteristics that influence IC disclosure. This is empirically tested using two models:

Intellectual Capital $_{i t}=a+\beta_{1}$ Shareholder control of the managers $_{\mathrm{it}}+\beta_{2}$ Board Independence $_{i t}+\beta_{3}$ Separation of roles $_{i t}+b_{4}$ Board Size $_{i t}+b_{5} Z_{i t}+v_{i t}$
Intellectual Capital ${ }_{i t}=a+\beta_{1}$ Shareholder control of the managers ${ }_{i \mathrm{t}}+\beta_{2}$ Board Independence $_{i t}+\beta_{3}$ Separation of roles ${ }_{i t}+b_{4}$ Board Size $_{i t}+b_{5}$ Board Size ${ }^{2}{ }_{i t}+b_{6} Z_{i t}+v_{i t}$

$$
\nu_{i t}=\mu_{i}+\varepsilon_{i t}
$$

Where: $i$ represents the company $(i=1, \ldots ., 23)$ and $t$ refers to the time period $(t=2004, \ldots \ldots$, 2008). $a$ is the constant, $b$ are the parameters that must be estimated. $v_{i t}$ is the random error term, which is decomposed into 2 parts: $\mu_{i}$ which is the individual effect that characterizes each company and is invariant over time; and $\varepsilon_{i t}$ that varies between companies and over time.

For the analysis, three estimators were used: Pooled Ordinary Least Squares (POLS), fixed effects (FE) and random effects (RE). If the term $v_{i t}=\mu_{i}+\varepsilon_{i t}$ (equation 3 ) is constant, there are no significant individual effects or temporal effects and the POLS assumes all terms are equal. If $\mu_{i}$ (equation 3) is assumed to be a fixed parameter, then it is estimated by $\mathrm{FE}$, and if $\mu_{i}$ (equation 3 ) is random, then the model is estimated by RE.

Aiming to determine the most accurate estimate, several tests were conducted (Hsiao, 2003; Wooldridge, 2010): the Breusch-Pagan test, the $\mathrm{F}$ test for FE, and the Hausman test.

In addition, the possible endogeneity of CG variables led us to use the HausmanTaylor estimator. This technique conforms to a random-effects model of panel data based on an instrumental variables approach, in which some of the covariables are correlated with unobserved random effects at the individual level (Wooldridge, 2010).

Estimates were run with Stata 14.1.

\section{Data analysis and results}

This section provides empirical results of our study, using descriptive and multivariate analyses. 


\section{I Descriptive analysis}

Results are presented in Table 4.

Table 4

\section{Descriptive statistics of Intellectual Capital Index and Corporate Governance Variables}

\begin{tabular}{lcccccc}
\hline & $\mathrm{N}$ & Minimum & Maximum & Mean & $\begin{array}{c}\text { Standard } \\
\text { deviation }\end{array}$ & Median \\
\hline $\begin{array}{l}\text { Intellectual Capital } \\
\begin{array}{l}\text { Shareholder control of } \\
\text { managers (\%) }\end{array}\end{array}$ & 115 & 0 & 0.70 & 0.42 & 0.20 & 0.50 \\
$\begin{array}{l}\text { Board Independence (\%) } \\
\text { Board Size }\end{array}$ & 115 & 0 & 60.46 & 12.910 & 19.39 & 3.66 \\
\hline & 115 & 9.09 & 80 & 40.66 & 17.03 & 41.18 \\
& & Frequency & Percentage & $\begin{array}{c}\text { Accumulated } \\
\text { percentage }\end{array}$ & Mean & $\begin{array}{l}\text { Standard } \\
\text { deviation }\end{array}$ \\
\hline Separation of Roles & $\begin{array}{c}\text { No Separation } \\
\text { Separation }\end{array}$ & 86 & 74.8 & 74.8 & 0.252 & 0.436 \\
\hline
\end{tabular}

The results show that companies disclose little about IC, with a mean value of $42 \%$. This result is similar to that obtained in previous studies (Bozzolan et al., 2003; Guthrie \& Petty, 2000). The average percentage of shares held by directors and managers is $13 \%$. The average percentage of the number of independent directors in the $\mathrm{BD}$ is $40.7 \%$. It is an acceptable percentage, taking into account that the CG code (CNMV, 2006, 2013 , 2015) recommends that it should be at least one-third of the total number of directors. Likewise, the average board size is 15 members. CG recommends (CNMV, 2006, 2013, 2015) that the $\mathrm{BD}$ be composed of a minimum of five and a maximum of 15 directors. Although separation of roles is advised, it only occurs in $25.2 \%$ of the cases.

\subsection{Multivariate analysis}

Table 5 shows the results of the regression models. From the third to the tenth column, the results of the POLS, FE, RE and robust RE estimates are presented, respectively. Columns 11 and 12 show the Hausman-Taylor estimate for both models.

For the first model (columns 3, 5, 7, 9 and 11 of Table 5), the Breusch-Pagan test $\left(\chi_{(01)}^{2}\right.$ $=89.29 ;$ p-value $=0.000)$ confirms that the RE estimate is more appropriate than the POLS. In addition, the $\mathrm{F}$ test $\left(\mathrm{F}_{22,86}=16.14 ; \mathrm{p}\right.$-value $=$ $0.000)$ shows that FE estimation is also more appropriate than the POLS. Finally, the Hausman test $\left(\chi_{(6)}^{2}=5.42 ; \mathrm{p}\right.$-value $\left.=0.491\right)$ confirms that the $\mathrm{RE}$ estimate is the most adequate. Moreover, it was estimated by robust standard errors and by cluster of companies (column 9). In the same way, the second model (columns 4, 6, 8, 10 and 12) was tested, and the results of the different tests confirm that the RE estimation is the best (Hausman: $\chi_{(7)}^{2}=4.18$; p-value $=0.759$ ). Column 12 shows the results of the RE with robust errors by cluster. 
Table 5

Static regression panel data models

\begin{tabular}{|c|c|c|c|c|c|c|c|c|c|c|c|}
\hline \multirow{2}{*}{$\begin{array}{l}\text { Variables } \\
\begin{array}{l}\text { Shareholder control } \\
\text { of the managers }\end{array}\end{array}$} & \multirow{2}{*}{$\begin{array}{l}\begin{array}{l}\text { Prediction } \\
\text { Sign }\end{array} \\
\mathrm{H} 1(+)\end{array}$} & \multicolumn{2}{|l|}{ POLS } & \multicolumn{2}{|l|}{ FE } & \multicolumn{2}{|l|}{$\mathbf{R E}$} & \multicolumn{2}{|c|}{$\begin{array}{l}\text { RE (Cluster } \\
\text { Robust) }\end{array}$} & \multicolumn{2}{|c|}{$\begin{array}{l}\text { Hausman-Taylor } \\
\text { (Cluster Robust) }\end{array}$} \\
\hline & & $\begin{array}{l}0.002 \\
(0.001) \\
(0.129) \\
\end{array}$ & $\begin{array}{l}0.002 \\
(0.001) \\
(0.199) \\
\end{array}$ & $\begin{array}{l}0.001 \\
(0.002) \\
(0.620) \\
\end{array}$ & $\begin{array}{l}0.001 \\
(0.002) \\
(0.623) \\
\end{array}$ & $\begin{array}{l}0.002 \\
(0.002) \\
(0.304) \\
\end{array}$ & $\begin{array}{l}0.002 \\
(0.002) \\
(0.339) \\
\end{array}$ & $\begin{array}{l}0.002^{* *} \\
(0.001) \\
(0.012) \\
\end{array}$ & $\begin{array}{l}0.002^{* *} \\
(0.001) \\
(0.022) \\
\end{array}$ & $\begin{array}{l}0.002^{*} \\
(0.001) \\
(0.068) \\
\end{array}$ & $\begin{array}{l}0.002^{*} \\
(0.001) \\
(0.062) \\
\end{array}$ \\
\hline Board Independence & $\mathrm{H} 2(-)$ & $\begin{array}{l}-0.002^{*} \\
(0.001) \\
(0.091)\end{array}$ & $\begin{array}{l}-0.002 \\
(0.001) \\
(0.201)\end{array}$ & $\begin{array}{l}-0.002 \\
(0.001) \\
(0.145)\end{array}$ & $\begin{array}{l}-0.002 \\
(0.001) \\
(0.161)\end{array}$ & $\begin{array}{l}-0.001 \\
(0.001) \\
(0.299)\end{array}$ & $\begin{array}{l}-0.001 \\
(0.001) \\
(0.374)\end{array}$ & $\begin{array}{l}-0.001 \\
(0.001) \\
(0.124)\end{array}$ & $\begin{array}{l}-0.001 \\
(0.001) \\
(0.203)\end{array}$ & $\begin{array}{l}-0.002^{* *} \\
(0.001) \\
(0.030)\end{array}$ & $\begin{array}{l}-0.002^{* *} \\
(0.001) \\
(0.035)\end{array}$ \\
\hline Separation of roles & $\mathrm{H} 3(+)$ & $\begin{array}{l}0.084^{*} \\
(0.046) \\
(0.071) \\
\end{array}$ & $\begin{array}{l}0.093^{* *} \\
(0.047) \\
(0.048) \\
\end{array}$ & $\begin{array}{l}0.112^{* * *} \\
(0.040) \\
(0.006)\end{array}$ & $\begin{array}{l}0.112^{* *} \\
(0.044) \\
(0.013) \\
\end{array}$ & $\begin{array}{l}0.090^{* *} \\
(0.037) \\
(0.014) \\
\end{array}$ & $\begin{array}{l}0.105^{* *} \\
(0.041) \\
(0.010)\end{array}$ & $\begin{array}{l}0.090^{* *} \\
(0.039) \\
(0.019) \\
\end{array}$ & $\begin{array}{l}0.105^{* *} \\
(0.044) \\
(0.018) \\
\end{array}$ & $\begin{array}{l}0.112^{\text {*** }} \\
(0.043) \\
(0.009)\end{array}$ & $\begin{array}{l}0.114^{* *} \\
(0.048) \\
(0.017) \\
\end{array}$ \\
\hline Board Size & $\mathrm{H} 4(+)$ & $\begin{array}{l}-0.021^{* * *} \\
(0.006) \\
(0.000)\end{array}$ & $\begin{array}{l}-0.067 \\
(0.042) \\
(0.114)\end{array}$ & $\begin{array}{l}0.008 \\
(0.008) \\
(0.324)\end{array}$ & $\begin{array}{l}0.008 \\
(0.049) \\
(0.869)\end{array}$ & $\begin{array}{l}-0.001 \\
(0.007) \\
(0.838)\end{array}$ & $\begin{array}{l}-0.032 \\
(0.042) \\
(0.450)\end{array}$ & $\begin{array}{l}-0.001 \\
(0.004) \\
(0.758)\end{array}$ & $\begin{array}{l}-0.032 \\
(0.032) \\
(0.317)\end{array}$ & $\begin{array}{l}0.008^{*} \\
(0.004) \\
(0.077)\end{array}$ & $\begin{array}{l}0.001 \\
(0.029) \\
(0.970)\end{array}$ \\
\hline Board Size ${ }^{2}$ & & & $\begin{array}{l}0.002 \\
(0.001) \\
(0.268) \\
\end{array}$ & & $\begin{array}{l}0.000 \\
(0.001) \\
(0.995) \\
\end{array}$ & & $\begin{array}{l}0.001 \\
(0.001) \\
(0.456) \\
\end{array}$ & & $\begin{array}{l}0.001 \\
(0.001) \\
(0.317) \\
\end{array}$ & & $\begin{array}{l}0.000 \\
(0.001) \\
(0.822) \\
\end{array}$ \\
\hline Company size & & $\begin{array}{l}0.058^{* * *} \\
(0.015) \\
(0.000) \\
\end{array}$ & $\begin{array}{l}0.060^{* * *} \\
(0.015) \\
(0.000) \\
\end{array}$ & $\begin{array}{l}0.077^{* *} \\
(0.031) \\
(0.014) \\
\end{array}$ & $\begin{array}{l}0.077^{* *} \\
(0.031) \\
(0.015) \\
\end{array}$ & & $\begin{array}{l}0.063 \\
(0.024) \\
(0.008) \\
\end{array}$ & $\begin{array}{l}0.062^{* * *} \\
(0.022) \\
(0.005)\end{array}$ & $\begin{array}{l}0.063^{* * *} \\
(0.022) \\
(0.004) \\
\end{array}$ & $\begin{array}{l}0.074^{* *} \\
(0.031) \\
(0.019) \\
\end{array}$ & $\begin{array}{l}0.074^{* *} \\
(0.031) \\
(0.018) \\
\end{array}$ \\
\hline Market to Book & & $\begin{array}{l}0.007 \\
(0.007) \\
(0.308) \\
\end{array}$ & $\begin{array}{l}0.006 \\
(0.007) \\
(0.418) \\
\end{array}$ & $\begin{array}{l}0.007 \\
(0.006) \\
(0.260) \\
\end{array}$ & $\begin{array}{l}0.007 \\
(0.006) \\
(0.262) \\
\end{array}$ & $\begin{array}{l}0.007 \\
(0.006) \\
(0.243) \\
\end{array}$ & $\begin{array}{l}0.007 \\
(0.006) \\
(0.253) \\
\end{array}$ & $\begin{array}{l}0.007 \\
(0.005) \\
(0.146) \\
\end{array}$ & $\begin{array}{l}0.007 \\
(0.005) \\
(0.148) \\
\end{array}$ & $\begin{array}{l}0.008 \\
(0.005) \\
(0.101) \\
\end{array}$ & $\begin{array}{l}0.008^{*} \\
(0.005) \\
(0.094) \\
\end{array}$ \\
\hline $\begin{array}{l}\text { Industry and } \\
\text { Construction }\end{array}$ & & $\begin{array}{l}0.122^{\text {** }} \\
(0.061) \\
(0.049) \\
\end{array}$ & $\begin{array}{l}0.146^{* *} \\
(0.065) \\
(0.026) \\
\end{array}$ & (omitted) & (omitted) & $\begin{array}{l}0.190 \\
(0.132) \\
(0.150) \\
\end{array}$ & $\begin{array}{l}0.195 \\
(0.136) \\
(0.152) \\
\end{array}$ & $\begin{array}{l}0.190 \\
(0.128) \\
(0.137) \\
\end{array}$ & $\begin{array}{l}0.195 \\
(0.122) \\
(0.110) \\
\end{array}$ & $\begin{array}{l}0.231^{*} \\
(0.138) \\
(0.095) \\
\end{array}$ & $\begin{array}{l}0.231^{*} \\
(0.138) \\
(0.094) \\
\end{array}$ \\
\hline Oil and Energy & & $\begin{array}{l}0.153^{* * *} \\
(0.056) \\
(0.007)\end{array}$ & $\begin{array}{l}0.166^{* * *} \\
(0.057) \\
(0.004)\end{array}$ & (omitted) & (omitted) & $\begin{array}{l}0.175 \\
(0.122) \\
(0.154) \\
\end{array}$ & $\begin{array}{l}0.180 \\
(0.127) \\
(0.156) \\
\end{array}$ & $\begin{array}{l}0.175 \\
(0.151) \\
(0.246) \\
\end{array}$ & $\begin{array}{l}0.180 \\
(0.147) \\
(0.220) \\
\end{array}$ & $\begin{array}{l}0.200 \\
(0.164) \\
(0.222) \\
\end{array}$ & $\begin{array}{l}0.200 \\
(0.163) \\
(0.220) \\
\end{array}$ \\
\hline Consumer Services & & $\begin{array}{l}-0.038 \\
(0.077) \\
(0.624) \\
\end{array}$ & $\begin{array}{l}-0.025 \\
(0.078) \\
(0.749) \\
\end{array}$ & (omitted) & (omitted) & $\begin{array}{l}0.002 \\
(0.173) \\
(0.991) \\
\end{array}$ & $\begin{array}{l}0.004 \\
(0.179) \\
(0.983) \\
\end{array}$ & $\begin{array}{l}0.002 \\
(0.130) \\
(0.988) \\
\end{array}$ & $\begin{array}{l}0.004 \\
(0.125) \\
(0.975) \\
\end{array}$ & $\begin{array}{l}0.020 \\
(0.141) \\
(0.886) \\
\end{array}$ & $\begin{array}{l}0.020 \\
(0.141) \\
(0.887) \\
\end{array}$ \\
\hline Consumer Goods & & $\begin{array}{l}-0.096 \\
(0.124) \\
(0.442) \\
\end{array}$ & $\begin{array}{l}-0.091 \\
(0.124) \\
(0.463) \\
\end{array}$ & (omitted) & (omitted) & $\begin{array}{l}0.051 \\
(0.252) \\
(0.839) \\
\end{array}$ & $\begin{array}{l}0.033 \\
(0.262) \\
(0.899) \\
\end{array}$ & $\begin{array}{l}0.051 \\
(0.157) \\
(0.745) \\
\end{array}$ & $\begin{array}{l}0.033 \\
(0.162) \\
(0.838) \\
\end{array}$ & $\begin{array}{l}0.160 \\
(0.164) \\
(0.331) \\
\end{array}$ & $\begin{array}{l}0.153 \\
(0.176) \\
(0.383) \\
\end{array}$ \\
\hline $\begin{array}{l}\text { Technology and } \\
\text { Telecommunications }\end{array}$ & & $\begin{array}{l}0.288^{* * *} \\
(0.076) \\
(0.000)\end{array}$ & $\begin{array}{l}0.316^{* * *} \\
(0.079) \\
(0.000)\end{array}$ & (omitted) & (omitted) & $\begin{array}{l}0.315^{*} \\
(0.171) \\
(0.065)\end{array}$ & $\begin{array}{l}0.331^{*} \\
(0.178) \\
(0.063)\end{array}$ & $\begin{array}{l}0.315^{* *} \\
(0.131) \\
(0.016)\end{array}$ & $\begin{array}{l}0.331^{\text {*** }} \\
(0.125) \\
(0.008)\end{array}$ & $\begin{array}{l}0.354^{* *} \\
(0.156) \\
(0.023)\end{array}$ & $\begin{array}{l}0.356^{* *} \\
(0.154) \\
(0.021)\end{array}$ \\
\hline Constant & & $\begin{array}{l}-0.327 \\
(0.275) \\
(0.237) \\
\end{array}$ & $\begin{array}{l}-0.053 \\
(0.368) \\
(0.885) \\
\end{array}$ & $\begin{array}{l}-1.004^{*} \\
(0.519) \\
(0.056) \\
\end{array}$ & $\begin{array}{l}-1.007 \\
(0.657) \\
(0.129) \\
\end{array}$ & $\begin{array}{c}-0.774^{*} \\
(0.447) \\
(0.084) \\
\end{array}$ & $\begin{array}{l}-0.571 \\
(0.542) \\
(0.292) \\
\end{array}$ & $\begin{array}{c}-0.774^{*} \\
(0.440) \\
(0.079) \\
\end{array}$ & $\begin{array}{l}-0.571 \\
(0.442) \\
(0.196) \\
\end{array}$ & $\begin{array}{c}-1.115^{*} \\
(0.579) \\
(0.054) \\
\end{array}$ & $\begin{array}{l}-1.064^{* *} \\
(0.519) \\
(0.040 \\
\end{array}$ \\
\hline $\begin{array}{l}\text { Number of } \\
\text { observations }\end{array}$ & & 115 & 115 & 115 & 115 & 115 & 115 & 115 & 115 & 115 & 115 \\
\hline $\mathrm{R}^{2}$ & & 0.328 & 0.3362 & 0.146 & 0.146 & 0.228 & 0.248 & 0.228 & 0.248 & & \\
\hline $\begin{array}{l}\text { Breusch-Pagan } \\
\text { Lagrange }\end{array}$ & & Model 1 & $\chi_{(01)}^{2}=89$ & 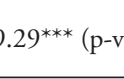 & lue $=0.000)$ & & Model 2 & $\chi_{(01)}^{2}$ & $=92.26^{* n+4}$ & -value $=0$ & \\
\hline$F$ test & & & $F_{(22,86)}=$ & $=16.14^{* * *}$ & value $=0.0$ & & & & $85)=15.85^{* *}$ & $*(\mathrm{p}$-value $=$ & $0.000)$ \\
\hline Hausman Test & & & $\chi_{(6)}^{2}=5$ & $.42(\mathrm{p}$-valu & $=0.491)$ & & & & $=4.18(\mathrm{p}-\mathrm{v}$ & lue $=0.75$ & \\
\hline
\end{tabular}

Note: Standard errors are included in parenthesis and the p-value below them. POLS: Pooled ordinary least squares, FE: Fixed Effects, RE: Random effects

*** Significant for $\mathrm{p}<0.01$; ${ }^{* *}$ Significant for $\mathrm{p}<0.05$; ${ }^{*}$ Significant for $\mathrm{p}<0.1$ 
The results for model 1 (column 9) confirm that, for a significance at 5\% level, higher shareholder control of the managers and separation of roles have a positive influence on IC disclosure $\left(\beta_{1}=0.002, \mathrm{p}\right.$-value $=0.011$; $\beta_{3}=0.090, \mathrm{p}$-value $=0.019$, respectively). The size of the company and the technology and telecommunications sector were also significant. These results can be confirmed for model 2 estimation (see column 10). In addition, the U-shaped relationship for the board size has not been significant.

The efficiency and robustness of our models is confirmed by the Hausman-Taylor estimation, robust by cluster of companies, (columns 11 and 12). The results for model 1 (column 11) show that a higher shareholder control of the managers improves IC disclosure for a significance at the $10 \%$ level $\left(\beta_{1}=0.002, \mathrm{p}\right.$-value $\left.=0.068\right) . \underline{\mathrm{H1}}$ is confirmed. This is consistent with the research of Bukh et al. (2005) made in companies in Denmark. A higher number of independent directors (Board Independence) refers negatively to IC disclosure at the $5 \%$ level $\left(\beta_{2}=-0.002\right.$, $\mathrm{p}$-value $=0.030) . \underline{\mathbf{H 2}}$ is accepted and confirms the results obtained by Al-Moataz and Hussainey (2012), Barako et al. (2006), Eng and Mak (2003), Gul and Leung (2004) and Rodrigues et al. (2017). For a significance level of $1 \%$, there is a positive relationship between the separation of roles and IC disclosure $\left(\beta_{3}=0.112\right.$, $\mathrm{p}$-value $\left.=0.009\right)$. This result confirms those obtained in previous researches (Allegrini \& Greco, 2013; Cerbioni \& Parbonetti, 2007; Hidalgo et al., 2011; Li et al., 2008; Rodrigues et al., 2017). $\mathbf{H 3}$ is accepted. The Board Size has a positive and significant influence with IC disclosure at the level the $10 \%$, $\left(\beta_{4}=0.008, \mathrm{p}\right.$-value $\left.=0.077\right)$. These results are also confirmed in the researches of Abeysekera (2010), Allegrini and Greco (2013) and Hidalgo et al. (2011). Thus, $\mathbf{H 4}$ is accepted. The technological and telecommunication sector, an intensive sector in IC, and the company size are also significant at the 5\% level (Bozzolan et al., 2003, Bukh et al., 2005, Rodrigues et al., 2017). No relationship was found between the ratio market to book and IC disclosure. Regarding model 2 (column 12) the same results are obtained for model 1, with the exception of the board size since the U-shaped relationship with IC disclosure is not significant.

\section{Discussion and conclusions}

In this paper, CG is analyzed as a mechanism that reduces the asymmetries of information and its influence on IC disclosure. In a context characterized by reduced legal protection to minority shareholders, a less developed capital market than the Anglo-Saxon, a monistic system of government determined by the relevance of the $\mathrm{BD}$, and the predominance of satisfying the interests of all stakeholders, CG is a determining factor for improving accountability and transparency in Spanish companies. For this, the companies belonging to the Ibex 35 over a period of five years are selected and the panel data methodology is used to capture the unobservable heterogeneity of the companies in the sample. In particular, the Hausman-Taylor estimator is used to solve the problem of endogeneity of CG variables.

Under the assumptions of the agencystakeholder theory, the results confirm that: $a$ ) the shareholder control of the managers is a mechanism that serves to protect the interests of shareholders and other stakeholders. Managers' ownership has a positive effect on the quality and the elaboration of the information. IC disclosure allows investors (and other stakeholders) to know the true value of the company, invest in it and increase the value of the shares; $b$ ) the presence of a higher number of independent directors in the BD has not proved to be an effective monitoring, supervision and advisory mechanism to disclose more information about the IC (it represents a mean percentage of 40.7, higher than recommended by Spanish CG Code). There has been a substitution effect due to the strong power of executive directors through the duality in the position of chairman and CEO (74.8\% of the sample) that leads them to participate little in the information disclosure 
policy and cannot protect the interests of all stakeholders. This power situation may moderate the role of independent directors by failing to ensure that their appointment is really due to their independence with the company and their professional training and prestige. In fact, it may happen that they are not sufficiently trained in issues referring to the IC and be afraid to support strategic decisions regarding its disclosure; c) the separation of roles is a useful mechanism to protect the interests of all parties which leads to greater transparency of information, improving the development and publication of IC information; d) a larger board size has a positive effect on IC disclosure, as much more knowledge and experience regarding IC is gathered by its members. The exchange of knowledge about the strategic value of IC leads to a greater motivation of the directors to participate in the strategic decision making on IC disclosure. In addition, there is no U-shaped relationship, i.e., it is not possible to confirm that the board size adversely affects IC disclosure, but to a certain extent, if a director is added to the $\mathrm{BD}$, that relationship becomes positive; and, e) the largest companies and those that belong to the technology and communications sector are the ones that provide more information.

With this study, we contribute to the agency-stakeholders theory through evidence from a non-Anglo-Saxon market (characterized by the strong power of executive directors and the low protection to minority shareholders and other stakeholders), that certain CG characteristics influence IC disclosure. These characteristics are a necessary mechanism for the good functioning of the capital market, reducing the asymmetries of information between the principal and the agent. The use of panel data provides more generalizable and robust results by taking into account different time periods.

Our results may be useful for: a) accounting regulators in the development of future recommendations and regulations referring to IC; b) the issuing agencies of CG codes for modifications to existing codes; $c$ ) the companies when adopting the recommendations of CG codes; and $d$ ) other countries with the same IC accounting regulation and with monistic systems of governance (mainly continental European countries).

In terms of practical implications, it is recommended that CG codes be revised in order to incorporate protection mechanisms for minority shareholders and other stakeholders, especially with regard to independent directors who must be highly qualified and trained professionals in IC related topics.

This study presents a series of limitations that could be overcome in future researches: a) the identification of the items that integrate the IC index was based on the subjective judgment of the researchers, according to previous literature, guidelines and recommendations of institutions. An unweighted index that assigns the same importance to each of the items was used. Future studies could be aimed at conducting interviews with the managers of the companies, in order to know the items that are most relevant to their company; b) IC information was obtained exclusively from annual reports. Subsequent studies could be aimed at using other means of collecting data, such as web pages, analyst reports, press releases etc.; c) the size of the sample is small and limited to studying the same Ibex35 companies over five years (balanced data). Future research should try to expand the sample size, incorporating companies that have been in the Ibex 35 over a certain period of time (unbalanced data). In addition, it would be interesting to transfer this research to companies that are not included in the index; $d$ ) the temporal and geographical horizon of the sample. We intend, in the future, to use available data from recent years to study the historical evolution during the period of economic crisis and find the effect that it has on the disclosure of IC information, transferring it to other capital markets that may have cultural and legal similarities (Latin America, Portugal, Italy, etc.) for a comparative study. 


\section{References}

Abeysekera, I. (2010). The influence of board size on intellectual capital disclosure by Kenyan listed firms. Journal of Intellectual Capital, 11(4), 504-518.

Abeysekera, I., \& Guthrie, J. (2005). An empirical investigation of annual reporting trends of intellectual capital in Sri Lanka. Critical Perspectives on Accounting, 16(3), 151-163.

Abhayawansa, S., \& Guthrie, J. (2016). Does intellectual capital disclosure in analysts' reports vary by firm characteristics? Advances in Accounting, 35, 26-38.

Acero Fraile, I. \& Alcalde Fradejas, N. (2010). Los consejos de administración: Una instantánea del caso español. Economía Industrial, 378, 159-168.

Alcaniz, L., Gomez-Bezares, F., \& Ugarte, J. V. (2015). Firm characteristics and intellectual capital disclosure in IPO prospectuses. Academia Revista Latinoamericana de Administración, 28(4), 461-483.

Allegrini, M., \& Greco, G. (2013). Corporate boards, audit committees and voluntary disclosure: Evidence from Italian listed companies. Journal of Management \& Governance, 17(1), 187-216.

Al-Moataz, E., \& Hussainey, K. (2012). Determinants of corporate governance disclosure in Saudi companies. Journal of Economics and Management, 5(1), 52-84.

An, Y., Davey, H., Eggleton, I. R., \& Wang, Z. (2015). Intellectual capital disclosure and the information gap: Evidence from China. Advances in Accounting, 31(2), 179-187.

Baltagi, B. (2014). Econometric analysis of panel data. London, England: Wiley.
Barako, D. G., \& Brown, A. M. (2008). Corporate social reporting and board representation: Evidence from the Kenyan banking sector. Journal of Management and Governance, 12(4), 309-324.

Barako, D. G., Hancock, P., \& Izan, H. (2006). Factors influencing voluntary corporate disclosure by Kenyan companies. Corporate Governance: An International Review, 14(2), 107-125.

Beattie, V. (2005). Moving the financial accounting research front forward: The UK contribution. British Accounting Review, 37(1), 85-114.

Beretta, S., \& Bozzolan, S. (2008). Quality versus quantity: The case of forward-looking disclosure. Journal of Accounting, Auditing \& Finance, 23(3), 333-376.

Botosan, C. A. (1997). Disclosure level and the cost of equity capital. Accounting Review, 72(3), 323-349.

Bozzolan, S., Favotto, F., \& Ricceri, F. (2003). Italian annual intellectual capital disclosure: An empirical analysis. Journal of Intellectual Capital, 4(4), 543-558.

Briano Turrent, G. C. \& Rodríguez-Ariza, L. (2013). Transparencia de la información corporativa en internet de las empresas del IBEX 35. Revista de Contabilidady Dirección, 16, 187-208.

Briano Turrent, G. C., \& Saavedra Garcia, M. L. (2015). The composition of the board and ownership structure as explanatory factors of transparency in corporate governance in Latin America: Evidence from listed companies in Argentina, Brazil, Chile and Mexico. Estudios Gerenciales, 31(136), 275-286.

Brooking, A. (1997). El capital intelectual: El principal activo de las empresas del tercer milenio. Barcelona: Paidós Empresa. 
Bukh, P. N., Nielsen, C., Gormsen, P., \& Mouritsen, J. (2005). Disclosure of information on intellectual capital in Danish IPO prospectuses. Accounting, Auditing and Accountability Journal, 18(6), 713-732.

Cerbioni, F., \& Parbonetti, A. (2007). Exploring the effects of corporate governance on intellectual capital disclosure: An analysis of European biotechnology companies. European Accounting Review, 16(4), 791-826.

Comisión Europea. (2006). Reporting intellectual capital to augment research, development and innovation in SMEs: Report to the Commission of the High Level Expert Group on RICARDIS. Luxemburgo: Oficina de Publicaciones Oficiales de las Comunidades Europeas.

Comisión Nacional del Mercado de Valores. (2006). Informe del grupo especial de trabajo sobre buen gobierno de las sociedades cotizadas. Madrid: Ministerio de Economía y Hacienda.

Comisión Nacional del Mercado de Valores. (2013). Código unificado de buen gobierno de las empresas cotizadas. Madrid: Ministerio de Economía y Hacienda.

Comisión Nacional del Mercado de Valores. (2015). Unified code of corporate governance: Informe del grupo especial de trabajo sobre buen gobierno de las sociedades cotizadas. Madrid: Ministerio de Economía y Hacienda.

Danish Agency for Trade and Industry. (2000). $A$ guideline for intellectual capital statements: $A$ key to knowledge management. Copenhagen: Author.

Danish Ministry of Science Technology and Innovation. (2003). Intellectual capital statements: The new guideline. Copenhagen: Author.

Eng, L. L., \& Mak, Y. T. (2003). Corporate governance and voluntary disclosure. Journal of Accounting and Public Policy, 22(4), 325345 .

Fernández-Méndez, C., Arrondo-García, R., \& Fernández-Rodríguez, E. (2011). Corporate governance and executive pay in the Spanish market. The Spanish Review of Financial Economics, 9(2), 55-68.

Federal Ministry of Economics and Labour. (2004). Intellectual capital statement: Made in Germany. Germany: Author.

García-Meca, E., Parra, I., Larrán, M., \& Martínez, I. (2005). The explanatory factors of intellectual capital disclosure to financial analysts. European Accounting Review, 14(1), 63-94.

García Osma, B., \& Gill de Albornoz, B. (2007). The effect of the board composition and its monitoring committees on earnings management: Evidence from Spain, Corporate Governance: An International Review, 15(6), 1413-1428.

García-Sánchez, I. M., Cuadrado-Ballesteros, B., \& Sepulveda, C. (2014). Does media pressure moderate CSR disclosures by external directors? Management Decision, 52(6), 1014-1045.

García-Sánchez, I. M., Rodríguez Dominguez, L., \& Gallego Álvarez, I. (2011). Corporate governance and strategic information on the internet: A study of Spanish listed companies. Accounting, Auditing \& Accountability Journal, 24(4), 471-501.

Ghazali, N., \& Weetman, P. (2006). Perpetuating traditional influences: Voluntary disclosure in Malaysia following the economic crisis. Journal of International Accounting, Auditing and Taxation, 15(2), 226-248.

Gisbert, A., \& Navallas, B. (2013). The association between voluntary disclosure and corporate governance in the presence of severe agency 
conflicts. Advances in Accounting, 29(2), 286-298.

Goebel, V. (2015). Intellectual capital reporting in a mandatory management report: The case of Germany. Journal of Intellectual Capital, 16(4),702-720.

Gul, F. A., \& Leung, S. (2004). Board leadership, outside directors' expertise and voluntary corporate disclosures. Journal of Accounting and Public Policy, 23(5), 351-379.

Guthrie, J., \& Petty, R. (2000). Intellectual capital: Australian annual reporting practices. Journal of Intellectual Capital, 1(3), 241-251.

Guthrie, J., Petty, R., Yongvanich, K., \& Ricceri, F. (2004). Using content analysis as a research method to inquire into intellectual capital reporting. Journal of Intellectual Capital, 5(2), 282-293.

Haniffa, R. M., \& Cooke, T. E. (2002). Culture, corporate governance and disclosure in Malaysian corporations. Abacus, 38(3), 317-349.

Hernández Sampieri, R., Fernández Collado, C., \& Baptista Lucio, P. (2006). Metodología de la Investigación. México: McGraw-Hill Interamericana.

Hidalgo, R. L., García-Meca, E., \& Martínez, I. (2011). Corporate governance and intellectual capital disclosure. Journal of Business Ethics, 100(3), 483-495.

Hill, C. W. L., \& Jones, T. M. (1992). Stakeholderagency theory. Journal of Management Studies, 29(2), 131-154.

Hsiao, C. (2003). Analysis of panel data. New York, NY: Cambridge University Press.

Instituto de Contabilidad y Auditoría de Cuentas. (2002). Informe sobre la situación actual de la Contabilidad en España y líneas básicas para abordar su reforma. Madrid: Autor.
Jensen, M. C., \& Meckling, W. H. (1976). Theory of the firm: Managerial behavior, agency costs and ownership structure. Journal of Financial Economics, 3(4), 305-360.

Krippendorff, K. (1997). Metodología de análisis de contenido: Teoría y práctica. Barcelona: Paidós Comunicación.

Ley 31/2014, de 3 de diciembre de 2014. Por la que se modifica la Ley de Sociedades de Capital para la mejora del gobierno corporativo. Recovered from https://www.boe.es/diario_ boe/txt.php?id=BOE-A-2014-12589

Li, J., Pike, R., \& Haniffa, R. (2008). Intellectual capital disclosure and corporate governance structure in UK firms. Accounting and Business Research, 38(2), 137-159.

Lim, S., Matolcsy, Z., \& Chow, D. (2007). The association between board composition and different types of voluntary disclosure. European Accounting Review, 16(3), 555-583.

Macagnan, C. B. (2009). Voluntary disclosure of intangible resources and stock profitability. Intangible Capital, 5(1), 1-32.

Marston, C. L., \& Shrives, P. J. (1991). The use of disclosure indices in accounting research: A review article. British Accounting Review, 23(3), 195-210.

Meritum Project. (2002). Guidelines for managing and reporting on intangibles. España: Fundación Airtel-Vodafone.

Ministry of Economy, Trade and Industry. (2005). Guidelines for disclosure of intellectual assets based management. Tokyo: Author.

Monclús Guitart, R., Rodríguez Merayo, M, A., \& Torres Coronas, T. (2006). Información sobre intangibles en la nueva economia: Un estudio sobre las prácticas de las empresas españolas cotizadas. Barcelona: ACCID. 
Monterrey Mayoral, J., \& Sánchez-Segura, A. (2008). Gobierno corporativo y calidad de la información contable: Evidencia empírica española. Revista de Contabilidad, 11(1), 67-100.

Nordic Industrial Fund. (2001). Intellectual capital: Managing and reporting: A report from the Nordika project. Oslo: NORDIKA.

Oliveras, E., Gowthorpe, C., Kasperskaya, Y., \& Perramon, J. (2008). Reporting intellectual capital in Spain. Corporate Communications: An International Journal, 13(2),168-181.

Ordoñez de Pablos, P. (2004). A guideline for building an intellectual capital statement: The 3R model. International Journal of Learning and Intellectual Capital, 1(1), 3-18.

Prado Lorenzo, J. M., García Sanchez, I. M. \& Gallego-Álvarez, I. (2009). Características del consejo de administración e información en materia de responsabilidad social corporativa. Revista Española de Financiación y Contabilidad, 38(141), 107-135.

Pucheta-Martínez, M. C. (2015). El papel del Consejo de Administración en la creación de valor en la empresa. Revista de Contabilidad, 18(2), 148-161.

Pucheta-Martínez, M. C., \& García-Meca, E. (2014). Institutional investors on boards and audit committees and their effects on financial reporting quality. Corporate Governance: An International Review, 22(4), 347-363.

Ríos Berjillos, A. de los, Torres Jiménez, M., Tirado Valencia, P., \& Carbonell Peralbo, A. (2009). Stakeholders, intangibles y generación de valor en las empresas del IBEX-35: Una estimación mediante modelos de panel. Revista Española de Financiación y Contabilidad, 38(142), 239-263.
Rodrigues, L. L., Tejedo-Romero, F., \& Craig, R. (2017). Corporate governance and intellectual capital reporting in a period of financial crisis: Evidence from Portugal. International Journal of Disclosure and Governance, 14(1), 1-29.

Rodríguez-Ariza, L., Frías-Aceituno, J. V. \& García Rubio, R. (2014). El consejo de administración y las memorias de sostenibilidad. Revista de Contabilidad, 17(1), 5-16.

Sveiby, K. E. (1997). The new organizational wealth: Managing \& measuring knowledgebased assets. San Francisco: Berrett-Koehler Publishers.

Tejedo-Romero, F. (2016). Información de los recursos intangibles ocultos: ¿memorias de sostenibilidad o informe anual? European Research on Management and Business Economics, 22(2), 101-109.

Tejedo-Romero, F., \& Alfaro-Cortés, E. (2014). Asociación entre las características empresariales y la divulgación sobre Capital Intelectual: Un estudio de las empresas del Ibex 35. Estudios de Economia Aplicada, 32(1), 371-398.

Tejedo-Romero, F., \& Araujo, J. F. (2016). Información del capital humano: La generación de intangibles y la responsabilidad social. Cuadernos de Gestión, 16(1), 125-144.

Vergauwen, P. G. M. C., Bollen, L., \& Oirbans, E. (2007). Intellectual capital disclosure and intangible value drivers: An empirical study. Management Decision, 45(7), 1163-1180.

Whiting, R. H., \& Miller, J. C. (2008). Voluntary disclosure of intellectual capital in New Zealand annual reports and the "hidden value". Journal of Human Resource Costing \& Accounting, 12(1), 26-50. 
Wooldridge, J. M. (2010). Econometric analysis of cross section and panel data. Cambridge: Massachusetts Institute of Technology Press.
Yi, A., \& Davey, H. (2010). Intellectual capital disclosure in Chinese (mainland) companies. Journal of intellectual capital, 11(3), 326-347.

\section{About the authors:}

1. Francisca Tejedo-Romero, Ph.D in Financial Economics and Accounting, University of Castilla-La Mancha, Spain. E-mail: Francisca.Tejedo@uclm.es

2. Joaquim Filipe Ferraz Esteves Araujo, Ph.D in Public Administration, University of Exeter, United Kingdom. E-mail: jfilipe@eeg.uminho.pt

3. Magnus Luiz Emmendoerfer, Ph.D in Sociology and Politics, Federal University of Minas Gerais, Brazil. E-mail:magnus@ufv.

\section{Contribution of each author:}

\begin{tabular}{lccc}
\hline Contribution & Francisca Tejedo-Romero & $\begin{array}{c}\text { Joaquim Filipe Ferraz } \\
\text { Esteves Araujo }\end{array}$ & $\begin{array}{c}\text { Magnus Luiz } \\
\text { Emmendoerfer }\end{array}$ \\
\hline $\begin{array}{l}\text { 1. Definition of research problem } \\
\text { 2. Development of hypotheses or research questions } \\
\text { (empirical studies) }\end{array}$ & $\sqrt{ }$ & $\sqrt{ }$ & \\
3. Development of theoretical propositions (theoretical & $\sqrt{ }$ & $\sqrt{ }$ & \\
Work) & $\sqrt{ }$ & $\sqrt{ }$ & $\sqrt{ }$ \\
4. Theoretical foundation/ Literature review & $\sqrt{ }$ & $\sqrt{ }$ \\
5. Definition of methodological procedures & $\sqrt{ }$ & $\sqrt{ }$ \\
6. Data collection & $\sqrt{ }$ & $\sqrt{ }$ \\
7. Statistical analysis & $\sqrt{ }$ & $\sqrt{ }$ \\
8. Analysis and interpretation of data & $\sqrt{ }$ & $\sqrt{ }$ \\
9. Critical revision of the manuscript & $\sqrt{ }$ & $\sqrt{ }$ \\
10. Manuscript Writing & $\sqrt{ }$ & & \\
11. Other - General orientation & & & \\
\hline
\end{tabular}

